\title{
Obsahy přirozených radioaktivních prvků (K, U, Th) v půdách na mapovém listu 24-22 Olomouc - vztah mezi radioaktivitou pưdy a matečné horniny
}

Contents of natural radioactive element $(K, U, T h)$ in soils on the map sheet 24-22 Olomouc - a relation between radioactivity of soil and parent rock

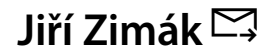

Katedra geologie PřF UP, 17. listopadu 12, 77146 Olomouc

\section{Key words:}

soils, limestones, Palaeozoic flysch formations, Tertiary marine sediments, fluvial sediments, loess, gamma-spectrometry, dose rate

凸 jiri.zimak@upol.cz

Editoři:

Milan Geršl, Marek Slobodník

\begin{abstract}
The paper deals with natural radioactivity of soils on the map sheet 24-22 Olomouc and compares contents of natural radioactive elements in soils and in their parent rocks (soilforming substrates). Three main types of parent rocks can be distinguished in the studied area: i) siliciclastic flysch sediments of the Moravo-Silesian Palaeozoic, ii) Quaternary sediments of the river Morava floodplain, iii) Quaternary loesses. Contents of potassium, uranium and thorium were measured using a laboratory gamma-ray spectrometer in 1077 soil samples. It is evident from calculated values of mass activity of ${ }^{226} \mathrm{Ra}$ equivalent $\left(a_{m}\right)$ that natural radioactivity of the studied soils is low. The average $a_{m}$ of soils developed on siliciclastic flysch sediments is $142 \mathrm{~Bq} \cdot \mathrm{kg}^{-1}, 133 \mathrm{~Bq} \cdot \mathrm{kg}^{-1}$ on fluvial sediments of the river Morava and $148 \mathrm{~Bq} \cdot \mathrm{kg}^{-1}$ on loesses. The average $a_{m}$ values calculated for soils developed on siliciclastic flysch sediments and for soils on loesses are almost the same as average $a_{m}$ values calculated for their parent rocks. The soils of the river Morava floodplain show higher $a_{m}$ values compared to their parent material (sands and pebbles dominate) due to higher uranium and thorium contents.
\end{abstract}

\section{Doporučená citace článku:}

Zimák, J. (2019). Obsahy přirozených radioaktivních prvků $(K, U, T h)$ $v$ půdách na mapovém listu 24-22 Olomouc - vztah mezi radioaktivitou půdy a matečné horniny. Geologické výzkumy na Moravě a ve Slezsku, 26, 1-2, 124-130.

DOI: https://doi.org/10.5817/ GVMS2019-1-2-124

\section{Úvod}

Mezi základní fyzikální parametry př́írodního prostředí patří jeho přirozená radioaktivita. Tento článek hodnotí přirozenou radioaktivitu půd na mapovém listu 24-22 Olomouc na základě výsledků laboratorního gamaspektromerického stanovení hlavních přirozených radioaktivních prvků (K, U a Th) v reprezentativním souboru 1077 půdních vzorků a přináší srovnání obsahu těchto prvků $\mathrm{v}$ půdách a matečných horninách (substrátech), na nichž se půdy vytvořily.

Geomorfologické členění, geologické jednotky a jejich horninová náplň

Z hlediska regionálního členění georeliéfu ČR (Bína, Demek 2012) je převážná část mapového listu 24-22 Olomouc součástí Hornomoravského úvalu, jenž je zde zastoupen podcelky Středomoravská niva, Prostějovská pahorkatina a Uničovská plošina. Západní okraj listu náleží k Bouzovské vrchovině, sv. cíp a v. okraj listu je součástí Domašovské vrchoviny.

Krystalinikum vystupuje na území hodnoceného mapového listu ve dvou malých ostrůvcích, tvořených kataklazovanými granodiority a diority, považovanými za součást brunovistulika (např. Bř́zová et al. 2000). Na krystaliniku jsou uloženy sedimenty moravskoslezského paleozoika, jehož zde nejstarším doloženým členem jsou devonská bazální klastika. Stratigraficky výše leží karbonátové horniny macošského a líšeňského souvrství. Nad nimi je mohutný 


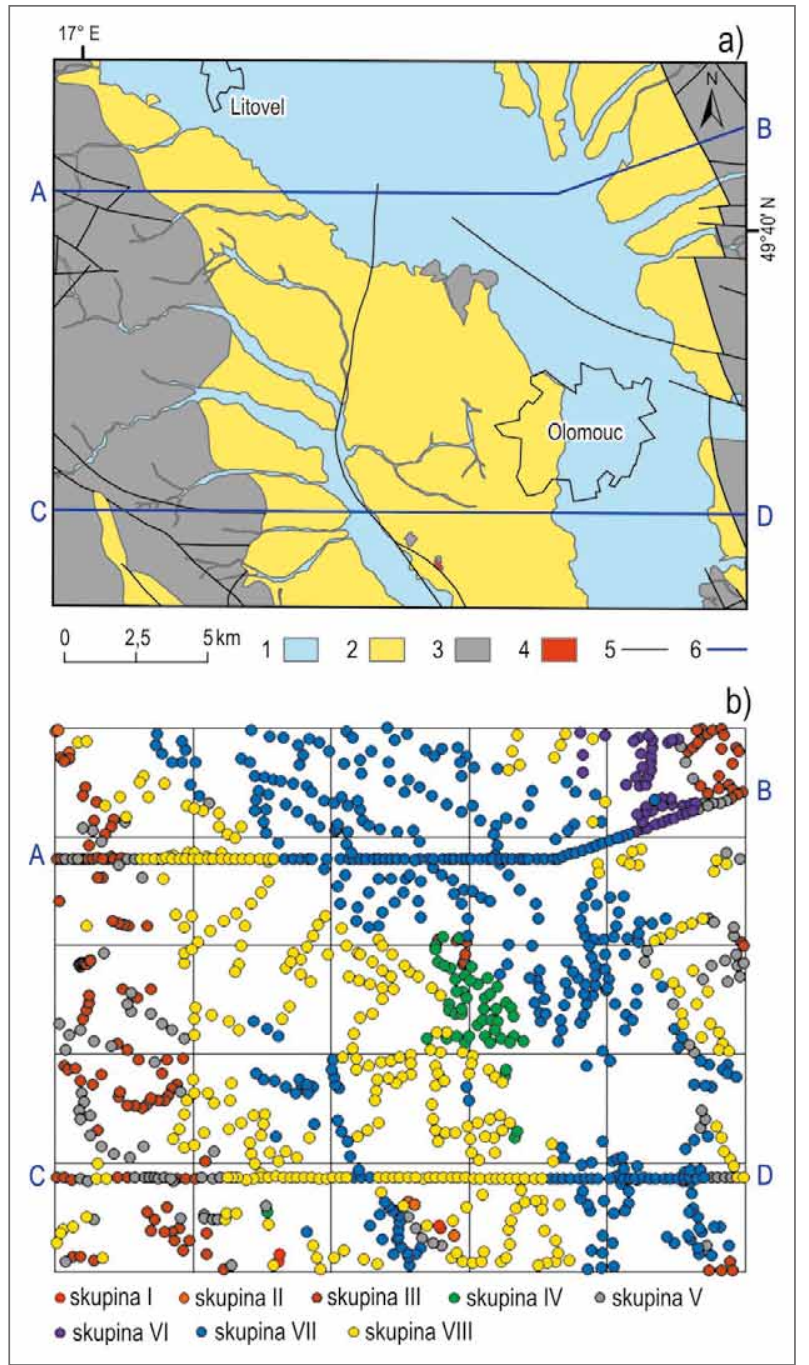

Obr. 1: a - Schéma geologických jednotek na mapovém listu 24-22 Olomouc. Legenda: 1 - fluviální sedimenty (kvartér); 2 - deluviální a deluviofluviální sedimenty a spraše (kvartér), písky, štěrky a jíly (pliocén), vápnité jíly (miocén); 3 - vápence (devon), droby a břidlice (spodní karbon); 4 - granit, granodiorit, diorit (brunovistulikum, proterozoikum); 5 - zlomy; 6 - linie (A-B, C-D) s detailním odběrem půdních vzorků; b - místa odběru půdních vzorků. Popis skupin půdních substrátů viz tab. 1 . Fig. 1: a - The scheme of geological units on the map sheet 24-22 Olomouc. Legend: 1 - fluvial sediments (Holocene, Quaternary); 2 - deluvial and deluvial-fluvial sediments, loess, loess soil (Quaternary), sands, gravels and clays (Pliocene), calcareous clays (Miocene); 3 - limestones (Devonian), graywacke and shales (Lower Carboniferous); 4 - granite, granodiorite, diorite (Brunovistulian, Proterozoic); 5 - faults; 6 - lines (A-B, C-D) with detailed sampling; $\mathrm{b}$ - Soil sampling sites. Description of soil substrate groups in Tab. 1 .

komplex siliciklastik (devon až spodní karbon), která mají charakter flyše, tvořeného hlavně drobami, siltovci, siltovými a jílovými břidlicemi. Tyto flyšové sedimenty (tzv. moravskoslezský kulm) náleží k šesti různým souvrstvím: andělskohorskému, protivanovskému, hornobenešovskému, rozstáňskému, moravickému a myslejovickému (Růžička et al. 1995).

Krystalinikum a moravskoslezské paleozoikum je na většině plochy listu překryto kenozoickými sedimenty (obr. 1). Jde o miocenní sedimenty karpatské předhlubně (vápnité jíly a písky), pliocenní lakustrinní a fluviální sedimenty (písky, jíly, silty a štěrky - tzv. „pestrý“ pliocén) a kvartérní uloženiny (hlavně fluviální a fluviolimnické písky, štěrky a jíly a také spraše) - viz Růžička et al. (1995).

\section{Typy půdotvorných substrátů a charakter půd}

Na území listu 24-22 Olomouc jsou zastoupeny obě hlavní kategorie půdotvorných substrátů (horizonty C) rozlišované v pedologické literatuře (např. Němeček et al. 1990): alterit, jenž se vytváří z „pevné“ matečné horniny v podloží (horizont $\mathrm{D}$ ), a pedolit, jímž jsou nezpevněné sedimenty. $\mathrm{V}$ případě alteritů jsou matečnými horninami proterozoické granitoidy a dioritoidy, paleozoické karbonátové horniny (tyto skupiny hornin zde mají jen malé rozšíření - viz tab. 1) a zejména siliciklastické sedimenty moravskoslezského kulmu, vystupují na území Bouzovské a Domašovské vrchoviny. Pedolity jsou reprezentovány kenozoickými fluviálními, lakustrinními a marinními sedimenty (štěrky, písky a jíly), přítomnými zejména ve Středomoravské nivě, a eolickými sedimenty (spraše), rozšířenými hlavně na území Prostějovské pahorkatiny.

Typ půdotvorného substrátu do značné míry určuje povahu půdy, která se na něm vytvořila (za daného stavu terénu a klimatických podmínek). To dokládají údaje $\mathrm{v}$ tabulce $1, \mathrm{v}$ níž jsou půdotvorné substráty rozděleny do osmi skupin, označených v této tabulce a následujícím textu jako I až VIII. Z tabulky 1 a obrázku 1 je zřejmé i rozšíření jednotlivých skupin půdotvorných substrátů a půdních typů na hodnoceném mapovém listu. K plošně významným zde patří půdotvorné substráty skupiny III, V, VII a VIII. Taxonomický klasifikační systém půd ČR (Němeček et al. 2001) rozděluje půdotvorné substráty do osmi tříd, označených písmeny A až $\mathrm{H}$, které jsou dále děleny na podtřídy, jejichž povaha je vyjádřena arabskými číslicemi. Na území listu 24-22 Olomouc odpovídají čtyři nejvýznamnější skupiny půdotvorných substrátů podtř́ídám A.1, B.2, B.3 a B.4 (skupina VII), B.5 (skupina VIII), B.6 (skupina V) a D.12 (skupina III). Rozšíření hlavních půdních typů na sledovaném území je zřejmé např. z publikace Hauptmana et al. (2009); dominantními typy půd jsou hnědozemě, černozemě a fluvizemě.

\section{Vzorky a metody}

Na mapovém listu 24-22 Olomouc bylo odebráno 1077 vzorků půd. Rozmístění míst odběru půdních vzorků je zřejmé $z$ obrázku $1 b$, v němž je barevně rozlišeno osm rozdílných typů substrátů. Mřižǩ v tom obrázku odpovídá hranicím mezi mapovými listy $\mathrm{v}$ měřítku 1 : 10 000. Relativně velké „bílé místo“ na 24-22-14 a 24-2215 je území Olomouce, na kterém odběry vzorků nebyly prováděny. Územím listu byly vedeny dva profily směru V-Z, každý o délce cca $25 \mathrm{~km}$, v každém bylo odebráno cca 100 vzorků, vzdálenost mezi sousedními místy odběru se pohybovala kolem $250 \mathrm{~m}$. Severní profil (označený jako profil A-B) začíná na z. okraji listu sz. od obce Loučka, směřuje k východu přes kótu Rampach, obec Unčovice, j. okraj Hynkova a obec Březce k toku řeky Oskavy, kde se lomí, a dále pokračuje vsv. směrem k v. okraji mapového 
Tab. 1: Základní údaje o osmi skupinách půdotvorných substrátů.

Tab. 1: Basic information on eight groups of soil-forming substrates.

\begin{tabular}{|c|c|c|c|}
\hline skupina & povaha půdotvorného substrátu & rozšíření & dominantní typ půdy \\
\hline I & granitoidy, dioritoidy & $\begin{array}{l}\text { ostrůvky při jižním okraji listu na k. ú. Třebčín, } \\
\text { Slatinky a Žerůvky }\end{array}$ & černozemě \\
\hline II & $\begin{array}{l}\text { karbonátové horniny macošského } \\
\text { a líšeňského souvrství }\end{array}$ & $\begin{array}{l}\text { ostrůvky v sz. cípu listu (k. ú. Měník, Mladeč, } \\
\text { Měrotín) a při j. okraji na k. ú. Slatinky a v pru- } \\
\text { hu mezi Hněvotínem a Bystročicemi (k. ú. } \\
\text { Hněvotín, Žerůvky, Nedvězí, Bystročice) }\end{array}$ & rendziny, sporadicky terrae calcis \\
\hline III & $\begin{array}{l}\text { siliciklastika andělskohorského, horno- } \\
\text { benešovského, moravického, protivanov- } \\
\text { ského, myslejovického a rozstáňského } \\
\text { souvrství (sp. karbon, kulm) }\end{array}$ & $\begin{array}{l}\text { při z. okraji listu (v. okraj Bouzovské vrchoviny), } \\
\text { méně na v. okraji listu (z. okraj Domašovské } \\
\text { vrchoviny) a elevace kulmu na k. ú. Horka nad } \\
\text { Moravou a Skrbeň }\end{array}$ & hnědozemě a kambizemě \\
\hline IV & tercierní sedimenty & $\begin{array}{l}\text { pruh mezi obcemi Skrbeň a Nemilany (hlavně } \\
\text { na k. ú. Skrbeň, Horka nad Moravou, Křelov, } \\
\text { Řepčín, Neředín, Nová Ulice, Slavonín) }\end{array}$ & hnědozemě, méně černozemě \\
\hline $\mathrm{V}$ & $\begin{array}{l}\text { kvartérní deluviální, deluviofluviální } \\
\text { a deluvioeolické sedimenty }\end{array}$ & $\begin{array}{l}\text { obvykle navazují na půdotvorné substráty sku- } \\
\text { piny III, plošně nejrozšířenější jsou na v. okraji } \\
\text { Bouzovské vrchoviny }\end{array}$ & $\begin{array}{l}\text { hnědozemě, lokálně kambizemě } \\
\text { a černozemě }\end{array}$ \\
\hline VI & štěrky výplavových kuželů & $\begin{array}{l}\text { sv. cíp listu (na k. ú. Stádlo, Moravská Huzo- } \\
\text { vá, Lhota u Šternberka, Štarnov, Bohuňovice, } \\
\text { Laštany) }\end{array}$ & hnědozemě \\
\hline VII & $\begin{array}{l}\text { kvartérní fluviální a fluviolimnické } \\
\text { sedimenty }\end{array}$ & $\begin{array}{l}\text { v pásu podél toku Moravy a též Oskavy a Bystři- } \\
\text { ce (to víceméně odpovídá podcelku Středomo- } \\
\text { ravská niva) a též podél menších vodních toků } \\
\text { na Prostějovské hornatině (Blata, Šumice) }\end{array}$ & $\begin{array}{l}\text { fluvizemě, lokálně hnědozemě } \\
\text { a černice }\end{array}$ \\
\hline VIII & kvartérní eolické sedimenty & $\begin{array}{l}\text { Prostějovská pahorkatina, méně Uničovská } \\
\text { plošina }\end{array}$ & černozemě \\
\hline
\end{tabular}

listu. Jižní profil (C-D) postupuje od z. okraje mapového listu kolem j. okraje obce Pěnčín k s. okraji Slatinic a dále kolem j. okraje Hněvotína a Slavonína přes Nové Sady kolem j. okraje Holice k v. okraji listu. Oba profily byly zvoleny tak, aby zastihly půdy na různých substrátech a probíhaly vně intravilánu (to byl důvod lomu na profilu A-B, který takto minul obec Laštany).

Většina nezastavěné plochy listu je zemědělsky využívána. Proto většina půdních vzorků pochází z orniční vrstvy. Na zalesněných plochách byly vzorky půd odebírány $\mathrm{z}$ hloubky zhruba $15 \mathrm{až} 20 \mathrm{~cm}$ pod povrchem (dominantně $\mathrm{z}$ horizontu $\mathrm{B}$ ), případné větší fragmenty hornin (nad cca $1 \mathrm{~cm}$ ) byly odstraněny již v terénu, příp. až po vysušení vzorků.

Před laboratorním gamaspektrometrickým stanovením obsahu přirozených radioaktivních prvků byly vysušené půdní vzorky uzavřeny do krabiček o objemu $250 \mathrm{ml}$. Hmotnost takto připravených vzorků se pohybovala kolem 300 gramů. Na PřF UP v Olomouci byly za použití spektrometru SG - $1000 \mathrm{LAB}$ s NaI(Tl) detektorem o objemu $0,35 \mathrm{dm}^{3}$ (průměr $76 \mathrm{~mm}$, délka $76 \mathrm{~mm}$ ) $\mathrm{v}$ půdních vzorcích stanoveny obsahy draslíku (přímo na základě koncentrace ${ }^{40} \mathrm{~K}$ ), uranu a thoria (na základě dceřiných produktů, a proto jsou jejich obsahy při uvádění výsledků analýz označovány jako eU a eTh). Meze detekce: $\mathrm{K}=0,5 \mathrm{hm}$. \%, U a Th = 1,5 ppm). Při výpočtu hodnot $\mathrm{a}_{\mathrm{m}} \mathrm{a} \mathrm{D}$ (viz níže) a při statistickém zpracování dat byly obsahy $\mathrm{K}$ pod mezí detekce nahrazeny hodnotou $0,33 \mathrm{hm} . \%$, obdobně v př́padě $\mathrm{U}$ a Th hodnotou $1 \mathrm{ppm}$.

Údaje o obsazích $\mathrm{K}, \mathrm{U}$ a Th $\mathrm{v}$ matečných horninách (substrátech skupin I až VIII) jsou založeny na výsledcích gamaspektrometrických analýz 728 horninových vzorků, provedených na témže spektrometru (podrobné hodnocení přirozené radioaktivity hornin na listu 24-22
Olomouc uvádí Zimák (2017), soubor horninových vzorků byl mírně rozšířen).

Přirozená radioaktivita půd a matečných hornin (substrátů) je hodnocena na základě hmotnostní aktivity ekvivalentu ${ }^{226} \mathrm{Ra}\left(\mathrm{a}_{\mathrm{m}}\right)$ a též dávkového př́íkonu záření gama terestrického původu (D). Tyto parametry byly Z výsledků gamaspektrometrických analýz vypočteny pomocí vztahů $\mathrm{a}_{\mathrm{m}}\left[\mathrm{Bq} \cdot \mathrm{kg}^{-1}\right]=(0,077 \times 313 \mathrm{~K})+12,35 \mathrm{U}+$ $(1,43 \times 4,06 \mathrm{Th}), \mathrm{D}\left[\mathrm{nGy} \cdot \mathrm{h}^{-1}\right]=(0,043 \times 313 \mathrm{~K})+(0,427 \times$ $12,35 \mathrm{U})+(0,662 \times 4,06 \mathrm{Th})$, do nichž je obsah K dosazován v hm. \%, obsahy U a Th v ppm (Beretka, Matthew 1985; UNSCEAR 1988; Matolín, Chlupáčová 1997; Ngachin et al. 200; Eštoková, Palaščáková 2013).

\section{Výsledky}

Výsledky všech laboratorních gamaspektrometrických stanovení obsahů $\mathrm{K}, \mathrm{U}$ a Th v půdách a matečných horninách (substrátech skupin I, II, III, IV, VII a VIII) jsou shrnuty v tabulce 2 , jejíž součástí jsou i vypočtené hodnoty $\mathrm{a}_{\mathrm{m}}$ a také hodnoty poměru průměrného obsahu sledovaného prvku v půdě k průměrnému obsahu tohoto prvku v matečné hornině, na níž se půda vytvořila. Hodnoty dávkového prŕḱnonu záření gama produkovaného osmi vyčleněnými skupinami půd jsou uvedeny v tabulce 3 , v prrípadě profilů $\mathrm{A}-\mathrm{B}$ a $\mathrm{C}-\mathrm{D}$ jsou vyjádřeny graficky na obrázku 2. Významné či zajímavé poznatky jsou komentovány v následující kapitole.

\section{Diskuze}

1. Průměrné hodnoty $\mathrm{a}_{\mathrm{m}}$ ve všech osmi skupinách půd rozlišovaných na základě povahy matečné horniny (substrátu) se pohybují v úzkém intervalu 120 až 149 $\mathrm{Bq} \cdot \mathrm{kg}^{-1}$ (tab. 2). Přirozenou radioaktivitu půd na listu 24-22 Olomouc je proto možno hodnotit jako poměrně 
Tab. 2: Obsahy přirozených radioaktivních prvků $(K, U, T h)$ v půdách a půdotvorných substrátech, vypočtené hodnoty hmotnostní aktivity ekvivalentu ${ }^{226} \mathrm{Ra}\left(\mathrm{a}_{\mathrm{m}}\right) ; \mathrm{n}=$ počet vzorků, $\mathrm{x}=$ průměr.

Tab. 2: Contents of the natural radioactive element (K, $\mathrm{U}, \mathrm{Th})$ in soils and soil-forming substrates, calculated mass activity of ${ }^{226} \mathrm{Ra}$ equivalent $\left(\mathrm{a}_{\mathrm{m}}\right) ; \mathrm{n}=$ number of samples, $\mathrm{x}=$ arithmetic mean.

\begin{tabular}{|c|c|c|c|c|c|c|c|c|c|c|c|c|c|c|c|c|c|}
\hline \multirow{2}{*}{ typ substrátu } & \multirow{2}{*}{$\mathrm{n}$} & \multicolumn{4}{|c|}{$\mathrm{K}(\mathrm{hm} . \%)$} & \multicolumn{4}{|c|}{ eU (ppm) } & \multicolumn{4}{|c|}{ eTh (ppm) } & \multicolumn{4}{|c|}{$\mathrm{a}_{\mathrm{m}}\left(\mathrm{Bq} \cdot \mathrm{kg}^{-1}\right)$} \\
\hline & & $\min$. & $\max$. & med. & $\mathrm{x}$ & $\min$. & $\max$. & med. & $\mathrm{x}$ & $\min$. & max. & med. & $\mathrm{x}$ & $\min$. & $\max$. & med. & $\mathrm{x}$ \\
\hline I - půda & 4 & 1,7 & 2,5 & 1,9 & 2,0 & 1,7 & 3,2 & 2,7 & 2,6 & 9,9 & 14,3 & 11,8 & 11,9 & 140 & 164 & 146 & 149 \\
\hline I - substrát & 11 & 2,2 & 3,7 & 2,8 & 2,9 & $<1,5$ & 2,9 & $<1,5$ & $<1,5$ & 3,2 & 15,3 & 7,3 & 7,7 & 84 & 190 & 126 & 130 \\
\hline I - půda/substrát & & & & & 0,69 & & & & $>2,0$ & & & & 1,55 & & & & 1,15 \\
\hline II - půda & 14 & 1,1 & 2,3 & 1,5 & 1,6 & $<1,5$ & 5,2 & 2,2 & 2,2 & 6,2 & 13,8 & 9,5 & 9,5 & 86 & 150 & 128 & 120 \\
\hline II - substrát & 83 & $<0,5$ & 1,1 & $<0,5$ & $<0,5$ & $<1,5$ & 2,6 & $<1,5$ & $<1,5$ & $<1,5$ & 4,0 & $<1,5$ & $<1,5$ & 26 & 63 & 26 & 30 \\
\hline II - půda/substrát & & & & & $>3,2$ & & & & $>1,5$ & & & & $>6,3$ & & & & $>4,0$ \\
\hline III - půda & 138 & 1,2 & 2,5 & 1,9 & 1,9 & 1,8 & 3,8 & 2,7 & 2,8 & 7,4 & 13,8 & 10,6 & 10,7 & 103 & 178 & 142 & 142 \\
\hline III - substrát & 448 & $<0,5$ & 3,7 & 2,1 & 2,1 & $<1,5$ & 7,4 & 2,1 & 2,2 & 2,6 & 28,7 & 10,5 & 10,7 & 35 & 345 & 138 & 139 \\
\hline III - půda/substrát & & & & & 0,90 & & & & 1,27 & & & & 1,00 & & & & 1,02 \\
\hline IV - půda & 50 & 1,0 & 2,2 & 1,7 & 1,6 & $<1,5$ & 3,6 & 2,3 & 2,4 & 5,3 & 12,1 & 9,5 & 9,6 & 70 & 150 & 124 & 125 \\
\hline IV - substrát & 82 & $<0,5$ & 2,3 & 1,5 & 1,4 & $<1,5$ & 3,1 & 1,6 & 1,6 & 1,6 & 12,2 & 8,1 & 7,4 & 30 & 150 & 103 & 96 \\
\hline IV - půda/substrát & & & & & 1,14 & & & & 1,50 & & & & 1,30 & & & & 1,30 \\
\hline V - půda & 103 & 1,6 & 2,4 & 1,9 & 1,9 & 1,7 & 4,6 & 2,9 & 2,9 & 7,6 & 13,1 & 11,1 & 11,0 & 109 & 167 & 146 & 145 \\
\hline VI - půda & 44 & 1,2 & 2,1 & 1,8 & 1,8 & 2,4 & 4,3 & 3,0 & 3,0 & 8,7 & 12,0 & 10,4 & 10,3 & 123 & 155 & 139 & 140 \\
\hline VII - půda & 395 & 0,7 & 2,2 & 1,7 & 1,7 & $<1,5$ & 12,4 & 2,7 & 2,8 & 5,0 & 14,2 & 10,0 & 9,9 & 64 & 256 & 134 & 133 \\
\hline VII - substrát & 83 & 1,0 & 2,3 & 1,6 & 1,6 & $<1,5$ & 3,1 & 1,5 & 1,6 & 2,2 & 12,0 & 5,0 & 6,2 & 56 & 145 & 86 & 95 \\
\hline VII - půda/substrát & & & & & 1,06 & & & & 1,75 & & & & 1,60 & & & & 1,40 \\
\hline VIII - půda & 329 & 1,3 & 2,8 & 1,9 & 1,9 & 2,0 & 4,6 & 3,0 & 3,0 & 9,2 & 25,6 & 11,3 & 11,3 & 128 & 269 & 147 & 148 \\
\hline VIII - substrát & 21 & 1,3 & 1,8 & 1,6 & 1,6 & 2,4 & 3,1 & 3,0 & 2,9 & 10,3 & 11,9 & 10,9 & 11,0 & 121 & 150 & 141 & 139 \\
\hline VIII - půda/substrát & & & & & 1,19 & & & & 1,03 & & & & 1,03 & & & & 1,06 \\
\hline
\end{tabular}

nízkou. Toto tvrzení vede $\mathrm{k}$ otázce, jaké hodnoty $\mathrm{a}_{\mathrm{m}}$ lze považovat za ještě nízké nebo naopak již vysoké. Jako nejlogičtější se jeví jejich porovnání s hodnotami $\mathrm{a}_{\mathrm{m}}$ vypočtenými $z$ klarků $K, U$ a Th. V literatuře uváděné klarky pro konkrétní chemický prvek se však často výrazně liší v závislosti na kvantitě a kvalitě dat i na způsobu jejich zpracování. Z klarkových hodnot zveřejněných Goldschmidtem v roce 1937 (viz napr. Bouška et al. 1980), kdy jde o 2,59 hm. \% K, 4 ppm U a 11,5 ppm Th, je za použití vztahů v kapitole „Vzorky a metody“ vypočtená $\mathrm{a}_{\mathrm{m}}$ 179 Bq.kg-1 (D = 87 nGy.h ${ }^{-1}$ ). Rudnick, Gao (2003) pro svrchní část zemské kůry kontinentálního typu uvádí 2,80 hm. \% $\mathrm{K}_{2} \mathrm{O}(=2,32 \mathrm{hm}$. \% K), 2,7 ppm U a 10,5 ppm Th, tomu odpovídá $\mathrm{a}_{\mathrm{m}} 150 \mathrm{~Bq} \cdot \mathrm{kg}^{-1}\left(\mathrm{D}=74 \mathrm{nGy} \cdot \mathrm{h}^{-1}\right)$. Z klarků vypočtených jinými autory (přehled poskytuje např. Rudnick - Gao 2003) lze odvodit jiné hodnoty $a_{m}$

Tab. 3: Vypočtený dávkový př́kon záření gama (D) produkovaného půdou vytvořenou na různých typech půdotvorných substrátů; $\mathrm{n}=$ počet vzorků, $\mathrm{x}=$ průměr.

Tab. 3: Calculated gamma radiation dose rate (D) produced by soil developed on different types of soil-forming substrates; $\mathrm{n}=$ number of samples, $\mathrm{x}=$ average.

\begin{tabular}{|c|c|c|c|c|c|}
\hline \multirow{2}{*}{ typ substrátu } & \multirow{2}{*}{$\mathrm{n}$} & \multicolumn{4}{|c|}{$\mathrm{D}\left(\mathrm{nGy}^{-1}\right)$} \\
\cline { 3 - 6 } & & min. & max. & med. & $\mathrm{x}$ \\
\hline I & 4 & 68 & 81 & 71 & 73 \\
\hline II & 14 & 42 & 73 & 62 & 58 \\
\hline III & 138 & 49 & 86 & 68 & 69 \\
\hline IV & 50 & 34 & 72 & 60 & 60 \\
\hline V & 103 & 53 & 80 & 71 & 70 \\
\hline VI & 44 & 59 & 74 & 67 & 68 \\
\hline VII & 395 & 31 & 118 & 65 & 64 \\
\hline VIII & 329 & 62 & 129 & 71 & 71 \\
\hline
\end{tabular}

a D. Pro posouzení míry radioaktivity půd na listu 24-22 Olomouc byla zvolena hodnota $\mathrm{a}_{\mathrm{m}}$ kalkulovaná $\mathrm{z}$ klarků Goldschmidta (po zaokrouhlení 180 Bq. $\mathrm{kg}^{-1}$ ).

Pouze dva vzorky půd $\mathrm{z}$ celého souboru $1077 \mathrm{stu}$ dovaných vzorků mají hodnotu $\mathrm{a}_{\mathrm{m}}$ vyšší než $180 \mathrm{~Bq} \cdot \mathrm{kg}^{-1}$. První z těchto vzorků byl odebrán na poli na k. ú. Drahanovice u osady Nová. Jde o černozem (vytvořenou na spraši - VIII), v níž bylo stanoveno 2,8 hm. \% K, 4,3 ppm eU a 25,6 ppm eTh $\left(\mathrm{a}_{\mathrm{m}}=269 \mathrm{~Bq} \cdot \mathrm{kg}^{-1}, \mathrm{D}=129 \mathrm{nGy} \cdot \mathrm{h}^{-1}\right)$. Druhým vzorkem je půda charakteru fluvizemě (na holocenních fluviálních sedimentech - VII) z pole na k. ú. Bohuňovice, obsahující 2,0 hm. \% K, 12,4 ppm eU a 9,4 ppm eTh $\left(\mathrm{a}_{\mathrm{m}}=256 \mathrm{~Bq} \cdot \mathrm{kg}^{-1}, \mathrm{D}=118 \mathrm{nGy} \cdot \mathrm{h}^{-1}\right)$ - anomálně vysoký obsah uranu v tomto vzorku je diskutován v bodě 5 .

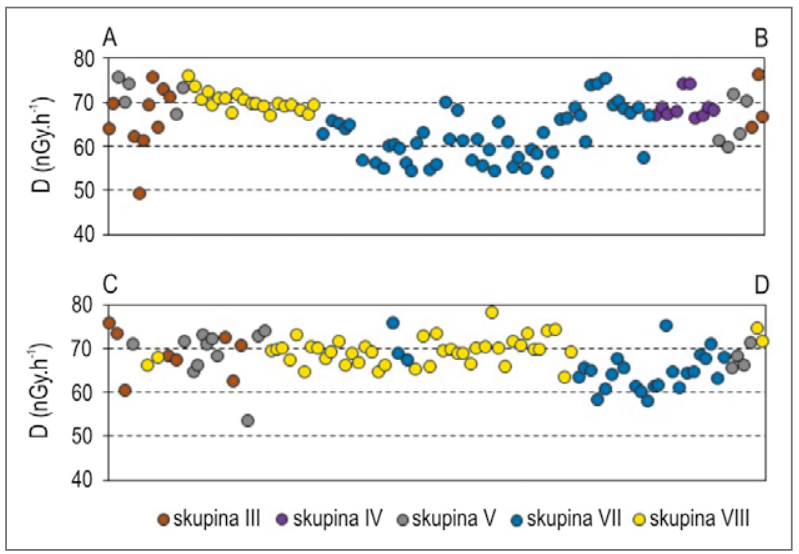

Obr. 2: Vypočtený dávkový př́ikon záření gama produkovaného půdou v profilech A-B a C-D.

Fig. 2: Calculated gamma radiation dose rate (D) produced by soil in lines A-B and C-D. 
Nutno doplnit, že průměrná hodnota globálního D je odhadována na 55 nGy.h-1 (UNSCEAR 1988, Manová, Matolín 1995), střední hodnota D pro území ČR je 65,6 \pm 19,0 nGy.h ${ }^{-1}$ (Manová, Matolín 1995). Na mapovém listu 24-22 Olomouc má osm vyčleňovaných skupin půd průměrné hodnoty $\mathrm{D} v$ rozpětí $58 \mathrm{až} 73 \mathrm{nGy} \cdot \mathrm{h}^{-1}$, tř̌i plošně nejvýznamnější skupiny půd (III, VII a VIII) v intervalu 64 až $71 \mathrm{nGy} \cdot \mathrm{h}^{-1}$ (tab. 3). Ve srovnání s údajem pro celé území ČR (viz výše) jde o hodnotu mírně vyšší.

2. Regionální pole přrirozené radioaktivity na hodnoceném mapovém listu je zásadním zpo̊sobem ovlivňováno půdami na třech skupinách substrátů označených jako III (kulmské sedimenty), VII (kvartérní fluviální sedimenty) a VIII (spraše) - viz obrázek 1, data v tabulkách 2 a 3 . Půdy na této trojici substrátů dominují i v obou profilech (obr. 1 a 2). Relativně nízká přirozená radioaktivita půd na kvartérních fluviálních sedimentech, vyjádřená formou dávkového př́konu záření gama, je zřejmá z obou profilů na obrázku 2 (modré body). Zejména profil A-B dokumentuje, že přirozená radioaktivita půd na fluviálních sedimentech ve východní části Stř̌edomoravské nivy je o něco vyšší než ve střední a západní části. Je to způsobeno rozdíly $\mathrm{v}$ přirozené radioaktivitě substrátu. Fluviální sedimenty střední a z. části obsahují hlavně klasty pocházející ze silezika a lugika, pro většinu jejichž hornin ve snosové oblasti jsou charakteristické relativně nízké obsahy všech tři gamaspoektrometricky sledovaných prvků (např. Zimák 2013, 2014). Na složení fluviálních sedimentů v. části Středomoravské nivy se zásadním způsobem podílí materiál pocházejí z kulmu jesenického bloku, jehož přirozená radioaktivita je výrazně vyšší (ve srovnání s krystalinikem silezika nebo lugika). Také profil C-D na obrázku 2 ukazuje zvýšení přirozené radioaktivity půd na fluviálních sedimentech ve v. části Středomoravské nivy, kde jsou půdy vyvinuty na výplavovém kuželu řeky Bystřice, a proto zde v klastickém materiálu výrazně dominují kulmské sedimenty (v tomto úseku profilová linie prochází přes tzv. Holickou rovinu). Zhruba ve střední části profilu $\mathrm{C}-\mathrm{D}$ jsou třemi vzorky zastoupeny půdy vytvořené na fluviálních sedimentech Blaty (mají charakter černice). Tyto tři půdní vzorky vykazují v rámci skupiny VII relativně vysokou přirozenou radioaktivitu. Jejich substrát je tvořen redeponovanou spraší a určitě se na jeho složení podílíi klastický materiál pocházející z Bouzovské vrchoviny, kde vystupují převážně kulmské sedimenty.

3. Přirozená radioaktivita půdotvorných substrátů a půd na nich vytvořených je $\mathrm{v}$ tabulce 2 vyjádřena pomocí hodnot $\mathrm{a}_{\mathrm{m}}$. Pokud je možno srovnání mezi $\mathrm{a}_{\mathrm{m}}$ půdy a půdotvorného substrátu provést, pak je zcela zřejmé, že $\mathrm{a}_{\mathrm{m}}$ půdy je vyšší nebo víceméně stejná ve srovnání $\mathrm{s} \mathrm{a}_{\mathrm{m}}$ odpovídajícího typu substrátu. Extrémní rozdíl byl zaznamenán $\mathrm{v}$ př́padě půd na karbonátových horninách, kdy je průměrná $\mathrm{a}_{\mathrm{m}}$ půdy více než čtyřnásobná v porovnání $\mathrm{s} \mathrm{a}_{\mathrm{m}}$ matečné horniny, a to díky vyšším koncentracím všech tří sledovaných prvků v půdě, zejména však $\mathrm{K}$ a Th (podobný trend uvádí např. Zimák 2015).

Půdy vytvořené na kulmských siliciklastikách (skupina III) a půdy na spraších (skupina VIII) vykazují

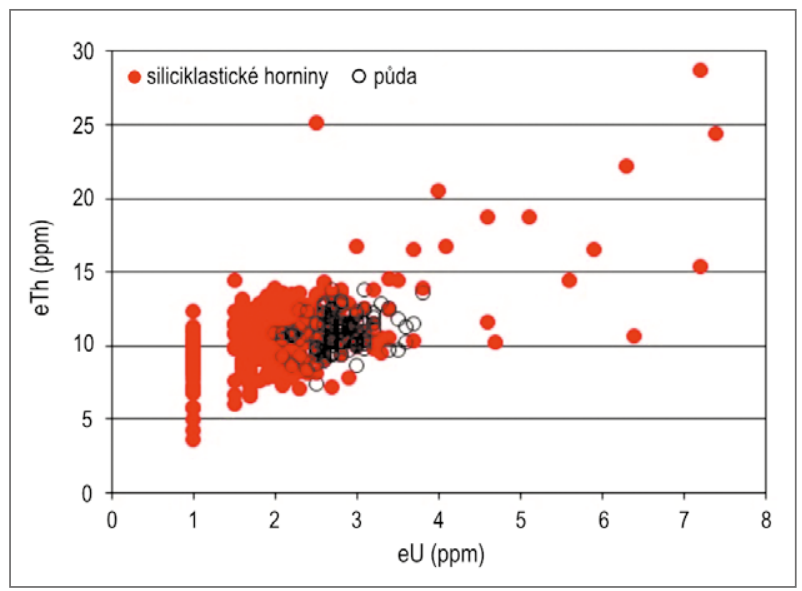

Obr. 3: Uran versus thorium v paleozoických siliciklastických sedimentech Bouzovské vrchoviny a v půdách na nich vytvořených.

Fig. 3: Uranium versus thorium in Palaeozoic siliciclastic sediments of the Bouzov Highlands and in soils developed on them.

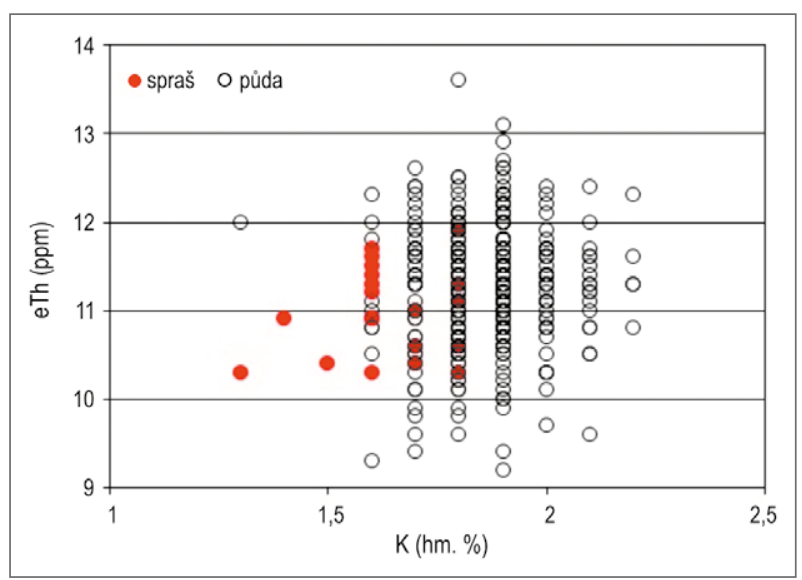

Obr. 4: Draslík versus thorium ve spraších a v půdách na nich vytvořených (na území Prostějovské pahorkatiny).

Fig. 4: Potassium versus thorium in loesses and in soils developed on them (at the Prostějov Upland).

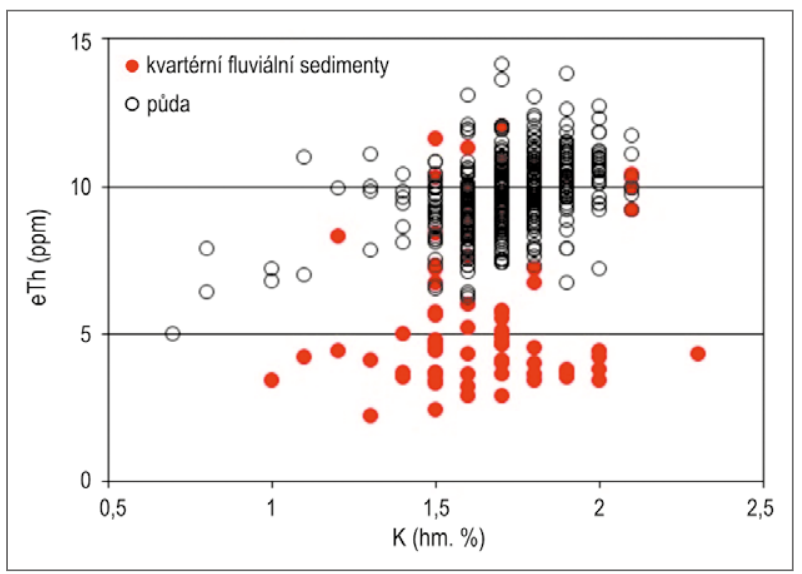

Obr. 5: Draslík versus thorium v kvartérních fluviálních sedimentech Středomoravské nivy a v půdách na nich vytvořených. Fig. 5: Potassium versus thorium in Quaternary sediments of the river Morava floodplain and in soils developed on them. 
shodnou nebo nepatrně vyšší přirozenou radioaktivitu než jejich půdotvorný substrát (viz data v tab. 2). Diagram uran versus thorium (obr. 3) dokumentuje značnou variabilitu v obsazích obou prvků ve flyšových sedimentech Bouzovské vrchoviny. Zimák (2017) dokládá, že obsahy uranu a thoria v kulmských siliciklastikách vystupujících na tomto území závisí jak na struktuře horniny, tak na prŕslušnosti k určitému souvrství: obsahy obou prvků rostou od psefitů přes psamity ke skupině aleuritů+pelitů, v rámci shodné strukturní skupiny sedimentů jsou obsahy obou prvků nižší v horninách protivanovského a myslejovického souvrství, vyšší v horninách rozstáňského souvrství (výrazné je to zejména ve skupině aleuritů a pelitů). Variabilita obsahů $U$ a Th v půdách vyvinutých na zvětralinách kulmských siliciklastik $\mathrm{v}$ prostoru Bouzovské vrchoviny je relativně nízká (tab. 2, obr. 3), $\mathrm{v}$ př́padě uranu je jeho průměrný obsah v půdě poněkud vyšší ve srovnání s matečnou horninou $(1,27 \times)$, průměrné obsahy thoria $\mathrm{v}$ půdě a matečné hornině jsou víceméně shodné. Přirozená radioaktivita půd na spraši (skupina VIII) je jen nepatrně vyšší než matečné spraše (tab. 2). Poměr draslík versus thorium ve spraši a v půdě na ní vytvořené vyjadřuje obrázek $4, \mathrm{v}$ němž jsou však půdy této skupiny reprezentovány pouze vzorky $\mathrm{z}$ prostoru Prostějovské pahorkatiny. Mírné zvýšení obsahu Kv půdě ve srovnání se spraší je z obrázku 4 zcela zřejmé.

4. Zajímavé je srovnání obsahů přirozených radioaktivních prvků v kvartérních fluviálních sedimentech a v půdách na nich vytvořených (skupina VII). Z údajů $\mathrm{v}$ tabulce 4 je zřejmé, že hodnota $\mathrm{a}_{\mathrm{m}}$ těchto půd je výrazně vyšší než fluviálních sedimentů $(1,40 \times)$, a to díky podstatně vyšším obsahům $U$ a Th. Obrázek 5 vyjadřuje poměr draslík versus thorium ve fluviálních sedimentech Středomoravské nivy a půdách na nich vzniklých. Výrazné zvýšení thoria $\mathrm{v}$ půdě je $\mathrm{z}$ toho obrázku patrné. Př́čcinou zvýšených obsahů U a Th půdě ve srovnání se vzorky fluviálních sedimentů může být skutečnost, že v souboru analyzovaných vzorků substrátu výrazně převažují písky a štěrky nad jemnozrnnějšími sedimenty. Zimák (2017) dokládá, že jíly v sedimentech Středomoravské nivy vykazují vyšší přirozenou radioaktivitu než písky a štěrky, a to díky vyšším obsahům U a Th. Srovnání obsahů U a Th v různých zrnitostních frakcích získaných ze vzorků sedimentů Středomoravské nivy rovněž ukázalo, že v aleuritové + pelitové frakci jsou vyšší obsahy obou prvků ve srovnání s frakcí psamitovou a psefitovou (Zimák 2017). Na území hodnoceného mapového listu jsou půdy Středomoravské nivy zastoupeny hlavně vegami (zaplavovanými jen mnohaletými vodami). Je proto pravděpodobné, že obsahy U a Th v nivní půdě jsou ovlivňovány jemnozrnným sedimentem, jenž se na povrchu půdy ukládá při občasných záplavách, přerušujících půdotvorný proces.

5. Radioaktivita půd na plochách dlouhodobě a intenzivně zemědělsky využívaných může být ovlivněna touto činností. Hnojení orné půdy může mít vliv na obsahy všech tř́ sledovaných prvků, zejména však $\mathrm{K}$ a $\mathrm{U}$. Aplikace hnojiv s obsahem $\mathrm{K}$ ve formě dostupné pro rostliny je nezbytně nutná, doplňuje draslík odčerpávaný vegetací (např. Zörb et al. 2014), avšak zásadnějším způsobem neovlivňuje relativně vysoký celkový obsah $\mathrm{K} v$ půdě. Dlouhodobá aplikace průmyslových fosforečných hnojiv (typu Superfosfát) nebo kombinovaných s obsahem fosfátů (Cererit, NPK) může vést ke zvýšení obsahu U v půdě. Fosforečná hnojiva vyráběná ze surovin pocházejících z ložisek sedimentárního původu mohou mít značné obsahy uranu, běžně $\mathrm{v}$ řádu desítek ppm, někdy i více než 100 ppm - vysoké koncentrace uranu v hnojivech mohou mít vliv nejen na radioaktivitu půdy, ale mohou být toxické pro rostlinstvo, dlouhodobá aplikace takových hnojiv může způsobit zvýšení koncentrace uranu v podzemní vodě se všemi následnými dopady (viz např. Guzmán et al. 1995; Yamazaki, Geraldo 2003; Liesch et al. 2015; Bigalke et al. 2018; Selvakumar et al. 2018). Německá „Komise pro ochranu půdy“ doporučila omezení koncentrace uranu v hnojivech legislativní cestou, kdy za mezní koncentraci považuje $50 \mathrm{mg}$ uranu na $1 \mathrm{~kg}$ $\mathrm{P}_{2} \mathrm{O}_{5}$ (na základě informace zveřejněné na wwww.agris. CZ v r. 2012). Autorovi tohoto článku se nepodařilo získat věrohodné informace o obsazích uranu ve fosforečných hnojivech používaných v současné době na území ČR, a proto provedl gamaspektrometrické stanovení K, U a Th v hnojivech zakoupených v olomouckých supermarketech. Analyzovaná hnojiva typu Cererit (NPK 8-13-11 a NPK 11-7-7) s obsahy $\mathrm{P}_{2} \mathrm{O}_{5}$ ve výši 13 a $7 \mathrm{hm}$. \% byla vyrobena v letech 2016 až 2018 firmami AGRO CS a.s., Lovochemie a.s. a Forestina s.r.o. Obsahy uranu byly v těchto hnojivech zjištěny $\mathrm{v}$ rozpětí $16-72 \mathrm{mg} \mathrm{U}$ na $1 \mathrm{~kg} \mathrm{P}_{2} \mathrm{O}_{5}$, průměr z osmi analyzovaných vzorků je $44 \mathrm{mg} \mathrm{U}$ na $1 \mathrm{~kg} \mathrm{P} \mathrm{O}_{5}$. Vzorek Superfosfátu $17 \%\left(\mathrm{tj} .17 \mathrm{hm} . \% \mathrm{P}_{2} \mathrm{O}_{5}\right.$ ) z roku 2018 (Forestina

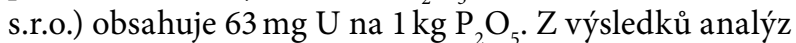
je zřejmé, že fosforečná hnojiva používaná v současnosti na území ČR mají často relativně vysoké obsahy uranu, $\mathrm{v}$ polovině vzorků přesahující výše navrhovanou limitní koncentraci $50 \mathrm{mg}$ U na $1 \mathrm{~kg} \mathrm{P} \mathrm{O}_{5}$. Nelze vyloučit, že v minulosti byla na našem území používána fosforečná hnojiva $s$ ještě podstatně vyššími obsahy uranu, a tedy s možnými negativními dopady. Ve vzorku hnojiva NPK 8-13-11 vyrobeného v roce 2004 (AGRO CS) bylo zjištěno $128 \mathrm{mg}$ $\mathrm{U}$ na $1 \mathrm{~kg} \mathrm{P}_{2} \mathrm{O}_{5}$. Nutno poznamenat, že v éře socialistické rostlinné výroby byly na jednotkovou plochu orné půdy aplikovány výrazně vyšší dávky průmyslových hnojiv než v současnosti. V bodě 1 zmíněná anomálně vysoká koncentrace uranu v nivní půdě u Bohuňovic $(12,4$ ppm eU) může být způsobena uranem z průmyslových hnojiv, která mohla být v místě odběru půdního vzorku dočasně deponována.

\section{Závěr}

Přirozenou radioaktivitu půd na mapovém listu 24-22 Olomouc lze hodnotit jako nízkou. Maximální průměrná hmotnostní aktivita ekvivalentu ${ }^{226} \mathrm{Ra}\left(\mathrm{a}_{\mathrm{m}}\right)$ vypočtená $\mathrm{z}$ obsahů $\mathrm{K}, \mathrm{U}$ a Th pro půdy na osmi rozlišovaných typech půdotvorných substrátů je jen $149 \mathrm{~Bq} \cdot \mathrm{kg}^{-1}$. Uvedená hodnota se týká půd vzniklých na proterozoických granitoidech a dioritoidech, jejichž plošný rozsah je zde nepatrný. Plošně nejvýznamnější jsou půdy na spraších (s průměrnou $\mathrm{a}_{\mathrm{m}}$ půdy $148 \mathrm{~Bq} \cdot \mathrm{kg}^{-1}$ ), půdy na kulmských 
siliciklastikách (142 Bq.kg-1) a nivní půdy (133 Bq.kg-1). Průměrné hodnoty $\mathrm{a}_{\mathrm{m}}$ půd na spraších a kulmských siliciklastikách jsou jen nepatrně vyšší ve srovnání s průměrnou $\mathrm{a}_{\mathrm{m}}$ jejich půdotvorných substrátů. Půdy Středomoravské nivy však mají průměrnou $\mathrm{a}_{\mathrm{m}}$ výrazně vyšší ve srovnání s fluviálními sedimenty s dominancí písků a štěrků v téže oblasti, a to díky vyšším obsahům uranu $(1,75 \times)$ a thoria $(1,60 \times)$. Obsahy U a Th v nivní půdě jsou pravděpodobně ovlivňovány jemnozrnným sedimentem, jenž se na povrchu půdy ukládá při občasných záplavách, přerušujících půdotvorný proces.

\section{Poděkování}

Poděkování za pomoc s technickým zpracováním grafiky patří Přemyslu Pořádkovi.

\section{Literatura}

Beretka, J., Matthew, P. J. (1985). Natural radioactivity of Australian building materials, industrial wastes and by-products. Health Physics, 48, 87-95. https://doi.org/10.1097/00004032-198501000-00007

Bigalke, M., Schwab, L., Rehmus, A., Tondo, P., Flisch, M. (2018). Uranium in agricultural soils and drinking water wells on the Swiss Plateau. - Environmental Pollution 233, 943-951. https://doi.org/10.1016/j.envpol.2017.09.061

Bína, J., Demek, J. (2012). Z nížin do hor: geomorfologické jednotky České republiky. - Academia Praha.

Bouška, V., Jakeš, P., Pačes, T., Pokorný, J. (1980). Geochemie. - Academia Praha.

Břízová, E., Čtyroká, J., Hanžl, P., Hladilová, Š., Hrubeš, M., Novák, Z., Švábenická, L., Zapletal, J. (2000). Geologický vývoj a charakteristika jednotek. - In: Hrubeš, M. (ed.): Vysvětlivky k základní geologické mapě České republiky $1: 25000$. List 24-224 Olomouc, 8-26. Český geologický ústav, Praha.

Eštoková, A., Palaščáková, L. (2013). Study of natural radioactivity of Slovak cements. - Chemical Engineering Transactions, $32,1675-1680$

Guzmán, E. R., Ríos, M. S., García, J. I., Regil, E. O. (1995). Uranium in phosphate rock and derivates. - Journal of Radioanalytical and Nuclear Chemistry, 189, 2, 301-306. https://doi.org/10.1007/BF02042609

Hauptman, I., Kukal, Z., Pošmourný, K. (2009). Půda v České republice. - Consult Praha.

Liesch, T., Hinrichsen, S., Goldscheider, N. (2015). Uranium in groundwater - Fertilizers versus geogenic sources. - Science of the Total Environment, 536, 981-995. https://doi.org/10.1016/j.scitotenv.2015.05.133

Manová, M., Matolín, M. (1995). Radiometrická mapa České republiky 1 : 500 000. - Český geologický ústav, Praha.

Matolín, M., Chlupáčová, M. (1997). Radioaktivní vlastnosti hornin. - In: Kobr, M. et al.: Petrofyzika, 109-126, Vydavatelství Karolinum, Praha.

Němeček, J., Macků, J., Vokoun, J., Vavř́íček, D., Novák, P. (2001). Taxonomický klasifikační systém půd České republiky. - Česká zemědělská univerzita, Praha.

Němeček, J., Smolíková, L., Kutílek, M. (1990). Pedologie a paleopedologie. - Academia, Praha.

Ngachin, M., Garavaglia, M., Giovani, C., Kwato Njock, M. G., Nourreddine, A. (2007). Assessment of natural radioactivity and associated radiation hazards in some Cameroonian building materials. - Radiation Measurements, 42, 61-67. https:// doi.org/10.1016/j.radmeas.2006.07.007

Rudnick, R. L., Gao, S. (2003). Vol. 3: The Crust, 3.01- The Composition of the Continental Crust. - In: Holland, H. D., Turekian, K. K. (eds): Treatise on Geochemistry, 1-64. Elsevier-Pergamon, Oxford. http://dx.doi.org/10.1016/b0-08-043751-6/03016-4

Růžička, M., Hrubeš, M., Dvořák, J. (1995): Geologická mapa ČR 1 : 50 000. List 24-22 Olomouc. - Český geologický ústav, Praha.

Selvakumar, R., Ramadoss, G., Menon, M. P., Rajendran, K., Thavamani, P., Naidu, R., Megharaj, M. (2018). Challenges and complexities in remediation of uranium contaminated soils: A review. - Journal of Environmental Radioactivity, 192 (2018), 592-603. https://doi.org/10.1016/j.jenvrad.2018.02.018

UNSCEAR, United Nations Scientific Committee on the Effects of Atomic Radiation (1988). Exposures from natural sources of radiation. Report to the General Assembly. - U. N., New York, USA.

Yamazaki, I. M., Geraldo, L. P. (2003). Uranium content in phosphate fertilizers commercially produced in Brazil. - Applied Radiation and Isotopes, 59, 133-136. https://doi.org/10.1016/S0969-8043(03)00159-3

Zimák, J. (2013). Přirozená radioaktivita metamorfovaných a magmatických hornin na mapovém listu 14-23 Králíky. - Geologické výzkumy na Moravě a ve Slezsku, 20, 157-161.

Zimák, J. (2014). Přirozená radioaktivita metamorfitů, magmatitů a předkenozoických sedimentů na mapovém listu 14-41 Šumperk. - Acta Musei Moraviae, Scientiae geologicae, 99, 2, 85-94.

Zimák, J. (2015). Vztah mezi přirozenou radioaktivitou hornin a půd na nich vytvořených - základní problém interpretace dat získaných leteckou a terénní gamaspektrometrií. - Geologické výzkumy na Moravě a ve Slezsku, 22, 1-2, 80-83. http:// dx.doi.org/10.5817/GVMS2015-1-2-80

Zimák, J. (2017). Přirozená radioaktivita krystalinika, paleozoických sedimentárních hornin a vybraných kenozoických sedimentů na mapovém listu 24-22 Olomouc. - Geologické výzkumy na Moravě a ve Slezsku, 24, 1-2, 65-68. http://dx.doi. org/10.5817/GVMS2017-1-2-65

Zörb, Ch., Senbayram, M., Peiter, E. (2014). Potassium in agriculture - Status and perspectives. - Journal of Plant Physiology, 171, 656-669. https://doi.org/10.1016/j.jplph.2013.08.008 